\title{
Chapter 3 \\ Southeast Asia and International Trade: \\ Continuity and Change in Historical \\ Perspective
}

\author{
Ryuto Shimada
}

\subsection{Introduction}

International trade has been an essential element of the long-term economic development of Southeast Asia. Involvement in international trade has laid crucial foundations for the present-day economic growth of this region since the fourth quarter of the twentieth century.

This chapter aims to provide a general overview of the relations between international trade and the economy of Southeast Asia from a long-term perspective. First, a short description is supplied about the relationships between natural endowments and international trade of Southeast Asia before the European arrival. The second section is devoted to an analysis of international trade of Southeast Asia from the beginning of the sixteenth century to the middle of the second half of the nineteenth century. This is then followed by a case study of Batavia's trade. The third section focuses on the economic influences of international trade on the Southeast Asian economy and society, including the change in the patterns of production, during the same period. The forth section returns to a survey of trade, to extend it to the high colonial period and its aftermath roughly to 1975, identifying several characteristics of the modern Southeast Asian economy along the way. Finally, the last section touches on the most recent period of industrialization, to show that the historically specific path laid by international trade has been critically important for the understanding of the long-term economic development of Southeast Asia.

Figure 3.1 is an illustration of the structure of this chapter. It was drawn to suggest that, if we take a few centuries together, there was normally an intermediate level of trade, which might be called intra-Asian trade, that often linked and organized other levels of trade. Intra-Asian trade is distinguished from both global longdistance trade, usually with Europe and the Americas, and local trade, including

\footnotetext{
R. Shimada ( $\bowtie)$

Graduate School of Humanities and Sociology, The University of Tokyo, Tokyo, Japan e-mail: r_shimada@nifty.com

K. Otsuka and K. Sugihara (eds.), Paths to the Emerging State in Asia and Africa, Emerging-Economy State and International Policy Studies, https://doi.org/10.1007/978-981-13-3131-2_3
} 

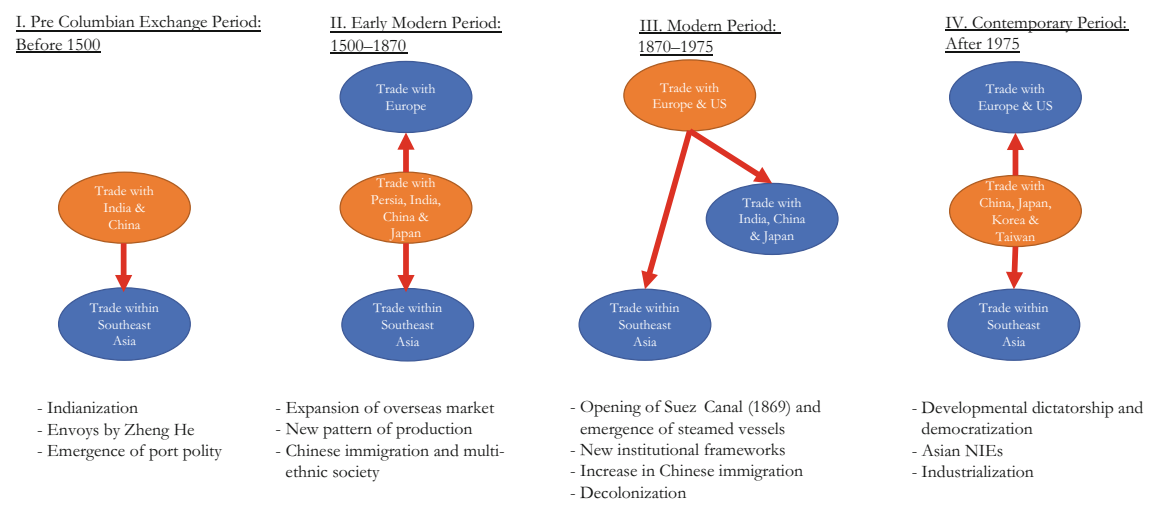

Fig. 3.1 International trade and socio-economic changes in Southeast Asia

intra-Southeast Asian trade. The implication of this formulation is that economy and society of the region have been developed by constant absorption of both Western and Asian civilizations through international trade and migration. Intra-Asian trade was the most significant driver of change of the Southeast Asian economy, although long-distance trade was the most important in the high colonial period. This chapter aims to examine the relationships of international trade and socio-economic changes of Southeast Asia, especially until the mid-twentieth century, along the line suggested by this figure.

In this chapter the 'early modern period' is defined in accordance with the periodization made from a perspective of global history rather than that of Southeast Asian history. It runs from the late fifteenth century, when Christopher Columbus "discovered" the Americas and the global economy became truly connected, to the middle of the second half of the nineteenth century, when steam vessels became dominant in place of sailing ships and global network of telegrams was created. Readers are reminded that this periodization does not follow the usual periodization in the historiography of Southeast Asia, where, for example, the early modern period is defined as from 1400 to 1830 by Barbara Watson Andaya and Leonard Y. Andaya (Andaya and Andaya 2015).

\subsection{Southeast Asia Before the European Arrival}

Reflecting the natural conditions of the tropics, the Southeast Asian economy experienced a path of economic development that is different from those in the temperate zone. Due to the high temperature and humidity in Southeast Asia, people were initially inclined to live in mountainous areas rather than in delta areas. In general, delta areas were an unfavorable place for people to live, because of the humidity and the high possibility of floods and the outbreak of infectious diseases such as malaria and 
dysentery. The difficulty of controlling large volumes of water was another reason for people's unwillingness to live in the delta. Thus most people lived in the cool and dry mountainous areas, and therefore did not utilize the delta areas by the seaside, an environment potentially richly endowed. For these reasons, Southeast Asia was comparatively sparsely populated during the pre-early modern period.

A major motivation for developing delta areas was to respond to the rise of profitable international maritime trade. High overseas demands for products supplied from the hinterland as well as large profits from transit trade inspired people to move and settle in lower areas from their mountainous dwellings. In this way, port cities such as Gresik in Java, Palembang in Sumatra and Ayutthaya in Thailand were established to facilitate maritime trade. These port cities were transport hubs where products from inland were gathered for export and overseas commodities were imported for distribution into the hinterland. Moreover, strong political regimes were often formed in such port cities. These political regimes are now called port-polity (Kathirithamby-Wells and Villiers 1990). In fact, Palembang and Ayutthaya are good examples of this, even though these ports were located far from the sea. These two cities were established at the point just between the plateau and the delta areas, which indicates that it was difficult to develop the delta areas at this time.

Historically, Southeast Asia engaged in two types of maritime trade. The first was intra-Asian trade. This type of trade has a very long history, spanning more than two thousand years. Geographically, it was of a very large scale. Since Southeast Asia is located between China and India, both of which had been powerful economic forces, Southeast Asia's trade developed along with the development of maritime trade of these Asian economic powers. Contacts with the Indian subcontinent had been significant over a longer period of time, as is reflected in India's strong cultural influence over Southeast Asia, which continues to this day. In addition, presentday Southeast Asia has Persian and Arabian imprints through the presence of the West Asian merchants who came to the region via maritime routes (Hall 2011). The kingdom of Champa is a good example to reveal the strong economic and cultural connections with China, India, and even West Asia. This kingdom, located in what is now mid-Vietnam, first had strong links with China around the third century, and sent tributary missions there. However, Champa began to be influenced by India and accepted Hindu culture, before the spread of Islamic influence began in the fourteenth century (Hardy et al. 2009).

Needless to say, Chinese influence has been as strong as Indian influence in Southeast Asia. The naval expeditions of Ming China between 1405 and 1433 directed by Zheng He, who was a Muslim Chinese admiral, and the tributary trade between Ming China and Southeast Asian states marked a climax of the intra-Asian trade before the European entry into Southeast Asia. The Ming imperial court sent large fleets seven times. The fleets visited Southeast Asia as well as Sri Lanka, the Indian subcontinent, the Arabian Peninsula, and East Africa. Due to the arrival of powerful fleets directed by Zheng He, Southeast Asian states in particular came under the strong political influence of Ming China. They sent to tributary missions to China and conducted maritime trade under the control of the Ming dynasty within the framework of the tributary system (Liu et al. 2014). 
The second type of maritime trade was a regional trade within Southeast Asia. Along with the development of intra-Asian trade, intra-regional maritime trade also began to grow. Not only coastal trade such as that in Java and Vietnam, but also a fairly long-distance trade was developed within Southeast Asia. The combination of intra-Asian trade with India and China and regional trade created a path of economic development based on international maritime trade. The proto-type of this path is evidenced through the records of Srivijaya from the seventh to the tenth century. Srivijaya was a federation of Malay cities among the Malay Peninsula, Sumatra Island, and Java Island. Each port city reaped profits and benefits from maritime trade and, in return, the unified kingdom was a recipient of Buddhism from the Indian subcontinent (Munoz 2006).

While Southeast Asia enjoyed the proto-type of trade-based economic development comprising intra-Asian and intra-regional trade by the fifteenth century (Fig. 3.1), its economy stepped into a new age of modernization at the beginning of the sixteenth century, when European traders began participating in economic activities. It was the beginning of the age of economic globalization when the Europeans began to connect Eurasia, Africa, and the Americas.

\subsection{Maritime Trade in the Early Modern Period}

The global economy entered a new stage at the beginning of the so-called Columbian exchange in the late fifteenth century (Crosby 1972), when the Americas were connected by Christopher Columbus and his followers. International connections truly developed on a global scale. As part of this global economic evolution, the Southeast Asian economy witnessed several changes.

Goa was conquered by the Portuguese in 1510 and became a center for the Portuguese maritime empire in Asia. In the next year, the Portuguese attacked the kingdom of Malacca (Melaka) gaining control of this key port in Southeast Asia. Soon the Portuguese also acquired the maritime lines to the Moluccas (Maluku Islands) and to Macau from Malacca. It is generally believed that gaining control of the Moluccas was highly important for Portuguese global trade, as the islands were the only place in the world where the valuable spices of clove, nutmeg, and mace were produced. These spices were key commodities in the Euro-Asian trade by the Portuguese in the sixteenth century.

The spice trade was one of the main sources of profits for the Portuguese empire. Indeed, the Portuguese were also engaged in intra-Asian trade, which also brought impressive profits. They had several trading bases in maritime Asia, some of which were Portuguese colonial cities such as Goa, Hormuz, Colombo, Malacca, and Macau. On the other hand, they also had trading posts in port cities under the control of Asian indigenous political regimes, such as Cambay (Khambhat) in Gujarat, Ayutthaya in Thailand and Nagasaki in Japan. Through their trading networks in maritime Asia, the Portuguese obtained large profits (Souza 1986). 
The history of the Portuguese provides us with a unique insight. It is true that the European arrival was a symbolic event in Southeast Asia during the early modern period. However, from the point of view of the region, the Portuguese were simply a new participant in Asia's maritime trade. The Portuguese were engaged in both intra-Asian trade and Euro-Asian trade, and these trading activities contributed to economic development of the region.

What the combination of Euro-Asian trade and intra-Asian trade could ultimately achieve were made much clearer by the Dutch East India Company (Verenigde Oostindische Compagnie, hereafter VOC), which existed from 1602 to 1799. The initial aim of the VOC was to directly procure Asian products for the European market. Spices such as pepper, nutmeg, mace, clove, and cinnamon in maritime Asia were the most desirable products for the VOC, although sugar, coffee, and tea emerged in the seventeenth and eighteenth centuries as other important Asian products. In order to acquire these products, the VOC brought American silver to Asia through Europe as a means of payment.

Besides Euro-Asian trade, the VOC attempted to participate in intra-Asian trade. Before the arrival of European traders to maritime Asia in the sixteenth century, intraAsian trade was conducted by several indigenous traders such as Arabs, Persians and Chinese. Through commercial negotiations and military actions, European traders came to join this branch of trade. In the sixteenth century, local Portuguese traders were one of the most powerful groups of traders, while in the seventeenth century, the VOC began engaging in intra-Asian trade on a much larger scale. The VOC was a unique participant, as it was a single organization, which conducted both long distance trade and intra-regional trade on a large scale. Other European companies such as English and French East India Companies were engaged in Euro-Asian trade without such a commitment in intra-regional trade (Shimada 2006).

It is impossible to disregard the magnitude of maritime trade conducted by indigenous Asian merchants. Asian traders were clearly more important than European traders in the early modern period. The most remarkable among them were Chinese merchants. Before the arrival of Europeans, Chinese merchants were actively engaged in intra-Asian trade. Not only Chinese traders, but also overseas Chinese traders conducted trade between Southeast Asia and China, while also participating in regional trade within Southeast Asia.

Set against this background, we see the emergence of the Chinese maritime network in the eighteenth century as a natural course of development. When political peace was realized in the late seventeenth century after the confusion caused by the Ming-Qing transition, the Chinese economy expanded, which caused greater demand for Southeast Asian products such as rice and tin. Some scholars refer to this period as "the Chinese century" (Reid 1997; Blussé 1999), indicating the influence of the Chinese economy, which grew in Southeast Asia through international trade with China by Chinese traders (see Chap. 4 of this volume).

Muslim traders were also important in Southeast Asia. Bugis and Malay traders were active in regional maritime trade in insular Southeast Asia from the second half of the eighteenth century (Barnard 2003). Their trading networks were also highly important in the context of the expansion of Islam. Through these networks, Arabian 
religious influence kept expanding, which enabled the immigration of Arabs from Hadhramaut into Insular Southeast Asia in the mid-eighteenth century (Abushouk and Ibrahim 2009).

\subsubsection{The Case of Batavia}

To examine the international economic links of Southeast Asia, the case of Batavia provides a helpful example. In general, the trade of Batavia had four spheres: long distance trade, intra-Asian trade, regional trade with the Indonesian archipelago, and coastal and inland trade (Table 3.1).

The long-distance trade of Batavia was first conducted by the VOC, which established the city in 1619. The office of Governor-General, who occupied the top position in business and military administration of the VOC governing the entire Asian waters was located in Batavia. The VOC was engaged in two types of maritime trade, as mentioned above. The first type of trade was Euro-Asian trade. The VOC supplied silver to Batavia from the Netherlands, and of course most silver was brought to Europe from Latin America. On the other hand, the VOC sent Asian products for the European market. Spices such as pepper, clove, nutmeg, mace, and cinnamon were major Asian products with great demand in Europe in the latter half of the seventeenth century, while Indian cotton textiles, Javanese sugar, Javanese coffee and Chinese tea became important in the course of time. Batavia played a key role of serving as the entrepôt to collect Asian products and ship them to the Netherlands. It acted as Asia's center of the Euro-Asian trade of the VOC.

In the nineteenth century, several Western private traders took the role of connecting Batavia with Europe and Americas. When the VOC perished at the end of the eighteenth century, the administration of Batavia and colonies in Java fell to the Dutch colonial authorities under the government of the Netherlands except for a short period from 1811 to 1816 , when the British occupied Java. Compared to the seventeenth and eighteenth centuries, the trade became open and its scale grew. In particular, with the freedom of participation, Western traders entered into the maritime trade of Java. Not only the Dutch, but also British, French, German, North European, and

Table 3.1 Four spheres of the trade of Batavia

\begin{tabular}{l|l|l}
\hline Sphere & Type of trade & Major trading partners \\
\hline 1 & Long-distance trade & The Netherlands, Europe, USA \\
\hline 2 & Intra-Asian trade & Japan, China, Siam, India, Persia \\
\hline 3 & $\begin{array}{l}\text { Regional trade within the Indonesian } \\
\text { archipelago }\end{array}$ & $\begin{array}{l}\text { Ambon, Bali, Bima, Banjarmasin, } \\
\text { Palembang }\end{array}$ \\
\hline 4 & Coastal and inland trade & $\begin{array}{l}\text { Semarang, Surabaya, Ommelanden, } \\
\text { Priangan }\end{array}$ \\
\hline
\end{tabular}


American traders called Javanese ports such as Batavia and Surabaya, and engaged in the business of Euro-Asian or American-Asian trade (Shimada 2013).

The sphere of intra-Asian trade in Batavia were also controlled mainly by the VOC. The VOC had several trading posts in maritime Asia from Japan to Arabia. By connecting these trading posts, it succeeded in developing several patterns of intraAsian trade. One representative pattern is the triangular trade that emerged between Japan, India and Southeast Asia. Japan exported silver, gold and copper to India. India then exported cotton textiles to Southeast Asia, where primary products such as sugar, sappanwood (a dye source), and deer hides were produced for the Japanese market. The VOC entered into this triangular trade with fierce force, and earned large profits. The profits from intra-Asian trade contributed to the success of the VOC, because the company was able to reduce the export of silver from the Netherlands to Asia and saved costs. For this intra-Asian trade Batavia was an important transit port in the VOC's shipping network, which linked up maritime Asian countries such as Japan, China, Siam, Mughal India, and Persia. This contributed to Asian economic development by establishing a system of international division of labor in maritime Asia, in which Batavia played a pivotal role in the VOC's trading network.

In these two spheres of trade, the Javanese economy played the role of exporting primary products. Sugar, coffee and later indigo were good examples. The huge demand for Javanese primary products was a stimulus for the economic development of Java and contributed to the growth of the port of Batavia.

The third sphere of trade was concerned with regional trade within the Indonesian archipelago. This trade was conducted mainly by Asian traders such as Chinese and Muslim traders, although it also involved the participation of the VOC in the seventeenth and eighteenth centuries and by private Western traders in the nineteenth century. The port of Batavia was not designed only for the Dutch vessels even in the seventeenth and eighteenth centuries. Indigenous Asian traders also utilized this port. Overseas Chinese traders in Batavia were the most significant customers of the port. While they accepted junk ships from mainland China and Chinese immigrants, they conducted their own shipping business. They sent their ships not only to other ports in Java such as Semarang and Surabaya but also to ports in the Indonesian archipelago like Bali and Banjarmasin (Shimada 2013). Their trading network formed a basis for the development of overseas Chinese power in the Indonesian archipelago. In this regional trading world, Batavia was one of the trading centers accustomed to importing and exporting regional products.

The fourth sphere was coastal trade and inland trade. Batavia was supplied with essential items like food products and timber through coastal trade. These products were necessary for the urban people of Batavia. This trade was conducted by Asian traders, the VOC and, later, Western private traders. In addition, the port of Batavia was an important port to which primary products could be sent from the hinterland. Already in the early eighteenth century, Batavia exported sugar produced in its suburban areas (Ommelanden) and coffee produced in Priangan. In this way, it was a significant trading port for the economic development of East Java (Jacobs 2006). 


\subsection{Social Changes in the Early Modern Period}

During the early modern period from the fifteenth century to the mid-nineteenth century, Southeast Asia experienced a change towards the formation of the modern economy and society (Fig. 3.1).

\subsubsection{Expansion of the Overseas Market}

European entry into Southeast Asia's international trade expanded the market for primary products from Southeast Asia. Simultaneously, tropical agricultural production was developed due to the large demand in the overseas market. In the sixteenth and seventeenth centuries, large volumes of spices were exported to Europe. Pepper was exported from Sumatra and Java, while nutmeg, mace, and clove were exported from the Moluccas. Besides spices, cane sugar and coffee bean were exported from Java since the seventeenth and eighteenth centuries, respectively. Apart from these agricultural products, tin was also an important Southeast Asian product for the European market. It was produced in southern Thailand, the Malay states of the peninsula and, since the eighteenth century, Bangka Island.

In addition to the European market, Asian demand for Southeast Asian products increased as well. Highly connected links within maritime Asia were spurred by the competition among Asian as well as European traders. Southeast Asia maintained and expanded their trade links with East Asia and South Asia. For example, Japan imported cane sugar from Java and sappanwood, rayskin, and animal hide from Thailand. China imported rice, tin and dried marine products such as sea cucumber from Southeast Asia. India imported cane sugar, spices and tin. In exchange for these products Southeast Asia obtained silver from East Asia and cotton textiles from South Asia (Shimada 2018).

Rice was the most important product for both intra-Asian trade and intra-Southeast Asian trade. Even before the European entry, Thai rice was exported to many areas in Southeast Asia. In addition to Thai rice, Javanese rice was traded in both intraSoutheast Asian and coastal and inland trade. It was exported to other parts of the Indonesian archipelago, and through coastal trade within the island of Java. As the surrounding zone of Batavia became specialized in the production of sugar cane, rice had to be imported into Batavia from northeast coastal area of the island. In the middle of the first half of the eighteenth century, Thailand began to export rice to China. This was because China was facing a shortage of rice due to the rapid population increase during the eighteenth century. This Thai rice trade with China became the key trade for the Thai economy until the twentieth century.

Intra-Asian trade was conducted not only by Asian traders but also by European traders. The latter, such as the VOC and English and Portuguese private merchants, as well as Chinese and Indo-Persian traders engaged in comparatively long-distance trade. On the other hand, Asian traders such as overseas Chinese, overseas Arab, and Bugis specialized in coastal trade and regional trade in Southeast Asia. Rice trade, interestingly, was not conducted by European traders but was left to Asian traders. 


\subsubsection{A New Pattern of Production}

Due to the growth of international trade, the mode of production changed over the course of time. One remarkable change was the introduction of the plantation system. Early European powers in Southeast Asia introduced the plantation system for sugar cane production. In the middle of the seventeenth century, the VOC attempted it in Taiwan. Although it was unsuccessful because of the abandoning of the Dutch colony in Taiwan in 1662, the VOC again attempted the introduction in Java on a large scale (Yao 2003). The Company sold the lands around Batavia to private European citizens, who in turn leased the land to Chinese entrepreneurs. These entrepreneurs managed the sugar cane cultivation and the cane sugar production for export (Blussé 1986). Laborers in this sugar industry were not only local Asians but also Chinese immigrants. In fact, overseas Chinese laborers outnumbered local Asians.

The mining sector too witnessed a change. Formerly, tin mining operated as a small-scale industry in southern Thailand and the Malay Peninsula. Tin was mined there by indigenous people as side work, and they contributed their products to the states as a sort of head tax. However, a new mode of production was introduced in the first half of the eighteenth century in Bangka and in the late eighteenth century in the Malay Peninsula. It involved a group of Chinese immigrant miners. Around fifty miners formed a group with a Chinese head, who was in charge of all the processes of mining and refinery (Shimada 2015). In addition to the tin mining sector, gold mining was also developing in West Borneo during the eighteenth century. The socalled Lanfang Republic (1777-1884) was a sort of state founded by prominent overseas merchants, who accumulated profits from gold mining in Borneo (Somers Heidhues 2003).

Without a doubt, the most predominant sector in Southeast Asia was the agricultural sector. It was traditional but was in transition. Recent research claims that in the early modern period small-scale, family-based patterns of agricultural production became widespread in the northern part of the mainland of Southeast Asia such as northern Vietnam and Burma (Lieberman 2003). This change in the unit of agricultural production was a similar phenomenon to that seen in East Asia, and resulted in an increase in living standards among small-scaled agricultural producers.

With regard to other parts of Southeast Asia, traditional patterns of small-scale agricultural production seem to have continued in the greater part of the agricultural sector. However, the fact that the traditional pattern evolved in response to the overseas demand cannot be ignored. Under the framework of the traditional small-scale family farming system, peasants had to work for a fixed number of days, for example a hundred days per year, to be submitted to the head of local community as tax. This compulsory labor system was authorized and exploited by European colonial authorities or local states, which could collect agricultural products for export through the heads of local community as efficiently as possible. The Dutch cultivation system of the nineteenth century is the best example (Elson 1994). 


\subsubsection{Immigration and Multi-ethnic Society}

The establishment of colonial cities in Southeast Asia was driven largely by the European merchants desire to increase their efficiency in international trade. Malacca, which was originally the capital of the state of Malacca, is a good example of a European colonial city. Yet, it was occupied by the Portuguese, followed by the Dutch and the British. Spanish Manila and Dutch Batavia are also typical examples of European colonial cities established in the early modern period. These two cities were the centers of trading business for the Spanish and Dutch merchants in the initial stage; they served as capitals of the Spanish/US Philippines and the Dutch East Indies in the nineteenth century and are currently two megacities in Southeast Asia.

Even in European colonial cities, Europeans did not comprise the majority of the population. It was made up of huge varieties of Asian ethnic groups. The population of Batavia, for example, included a large number of Chinese immigrants with some Malay, Bugis, Balinese, Indo-Persians, and so on. These Asian populaces were mostly immigrants to the colonial city. Batavia in 1699 had a population of 21,911. Among them, European citizens accounted for only $8 \%$, the Chinese 17\%, Asian Portuguese freed-slaves (mardijker) 11\%, South Asians 2\%, Malay and Javanese 1\%, and the Balinese and Makassarese 1\%, although Asian slaves, who were immigrants or their descendants, accounted for more than the half of the total population (Raben 1996).

Being composed of several ethnic immigrants, these colonial cities were literally multi-ethnic societies. Through the long history of multi-ethnicity since the early modern period, the Southeast Asian society has accumulated the experiences of and benefits from multi-ethnic culture. This provided a powerful socio-cultural basis for the economy and society, which would willingly attract and accept immigrants, foreign products, overseas technology, and international trade.

\subsection{The High Colonial Period and After}

Throughout the nineteenth century, international trade rapidly increased in Southeast Asia. Although Table 3.2 shows the steady rise of merchandise exports from Southeast Asia from the first half of the nineteenth century to the end of the twentieth century, the whole structure of international trade and the economy of Southeast Asia changed drastically around 1870 .

First, in terms of international trade, long-distance trade with Europe and USA expanded, as seen in Table 3.3. It was because of the increase in exports of primary products and imports of cotton textiles. Southeast Asia exported rubber, sugar, coffee, and tea while it imported manufactured goods from Europe and USA where industrialization was in progress. Moreover, the opening of the Suez Canal was a turning point not only in terms of shipping but also in terms of the impact on the whole economy. The canal was opened in 1869 and a huge number of Western steam 
Table 3.2 Merchandise Exports at Current Price, 1870-1998 (million dollars at current exchange rates)

\begin{tabular}{l|l|l|l|r|r|r|r}
\hline Year & 1820 & 1870 & 1913 & 1950 & 1973 & \multicolumn{1}{l}{1990} & \multicolumn{1}{l}{1998} \\
\hline Burma & - & - & - & 303 & 358 & 1,671 & 3,831 \\
\hline Indonesia & 31 & 270 & 582 & 800 & 3,211 & 25,675 & 48,847 \\
\hline Philippines & 29 & 48 & 163 & 331 & 1,885 & 8,068 & 27,783 \\
\hline Thailand & 7 & 43 & 94 & 304 & 1,564 & 23,071 & 54,455 \\
\hline Total & 67 & 361 & 839 & 1,738 & 7,018 & 58,485 & 134,916 \\
\hline
\end{tabular}

Source Maddison 2001: 360

Table 3.3 Trading Partners of International Trade in Southeast Asia, 1883-1938 (million pounds sterling)

\begin{tabular}{|c|c|c|c|c|c|c|c|c|c|c|}
\hline & \multicolumn{2}{|l|}{1883} & \multicolumn{2}{|l|}{1898} & \multicolumn{2}{|l|}{1913} & \multicolumn{2}{|l|}{1928} & \multicolumn{2}{|l|}{1938} \\
\hline & $\begin{array}{l}\text { The } \\
\text { west }\end{array}$ & Asia & $\begin{array}{l}\text { The } \\
\text { west }\end{array}$ & Asia & $\begin{array}{l}\text { The } \\
\text { west }\end{array}$ & Asia & $\begin{array}{l}\text { The } \\
\text { west }\end{array}$ & Asia & $\begin{array}{l}\text { The } \\
\text { west }\end{array}$ & Asia \\
\hline Export & 15.0 & 6.7 & 15.2 & 14.7 & 56.8 & 42.2 & 142.4 & 90.9 & 94.2 & 46.4 \\
\hline Import & 13.5 & 8.4 & 16.0 & 14.2 & 48.0 & 31.7 & 96.8 & 59.1 & 63.9 & 35.7 \\
\hline
\end{tabular}

Note Asia includes China, Japan and India only

Sources Sugihara 1996: 14, 96-97

vessels annually called on Southeast Asian ports. The shipping services were run by Western companies, which brought the Southeast Asian economy closer to the global market.

In addition to the global spread of steam vessels, the British policy of free trade spurred international trade in Southeast Asia. It is true that Southeast Asia comprised formal colonies under the British, Dutch, French, Spanish, and American empires, except for Thailand. Yet, basically, the order of international trade was fixed by the British policy of free trade, which was followed by other Western countries, and the policies of the Netherlands in particular. Singapore was established as the most important center in Southeast Asia for global and regional trade (see Chap. 5 of this volume). The trading network became well-equipped, as the facilities of the key ports improved and commercial institutions such as banking in sub key ports such as Batavia and Manila were modernized (Sugihara 2001).

Second, thanks to the emergence of long-distance trade with the West, intra-Asian trade expanded. Table 3.3 shows the values of intra-Asian trade, which comprised trade between Southeast Asia and other parts of Asia (exactly speaking, it means trade with China, Japan, and India). Although intra-Asian trade never exceeded trade with the West, it also rapidly expanded from 1883 to 1928 . This growth was realized by Asian factors as well. Alongside the economic development of Japan, India, and China over the course of time, Southeast Asia expanded the market for its primary products in these countries. Furthermore, Southeast Asia imported manufactured goods such as cotton textiles and miscellaneous products like matches, tooth brushes, 
and medicine especially from Japan in the first half of the twentieth century (Kagotani 1995).

Third, intra-Southeast Asian trade also expanded. Rice trade was especially important. Rice cultivation expanded in the delta areas in Mainland Southeast Asia as well as Java. This rice was exported to countries outside Southeast Asia but also to insular Southeast Asia except for Java, where imported rice was a crucial commodity for the laborers engaged in plantation agriculture.

International trade in this high colonial period, however, was a sort of exceptional case in the history of Southeast Asia. In general, the engine of international trade was intra-Asian trade with India and East Asia. Yet, in this period, trade with the West became the engine that drove the entire international trade of Southeast Asia. Nevertheless, similar to other periods, Southeast Asia played the role of supplying primary products, while it imported manufactured goods from outside the region. This equation continued even after World War II, until the mid-1970s.

To sum up, Southeast Asia stepped into the high colonial period in the fourth quarter of the nineteenth century, causing an increase in international trade, which was led by long-distance trade with the West. This development in international trade influenced Southeast Asia's economy and society. In the process of responding to rising overseas demand for Southeast Asian products, the economy experienced the development of the agricultural sector, which resulted in economic growth, as well as the growth of population. ${ }^{1}$

In addition to economic and population growth, what were the other features of this period that have influenced the direction of economic development which remained after independence? The following two points stand out.

\subsubsection{The New Institutional Framework}

The colonial authorities and the Thai government attempted to introduce the modern landholding system, but in vain. However, in terms of commercial and financial affairs, the authorities succeeded in introducing modern institutions for economic growth. An example of this is the banking system for the supply of capital.

In the late nineteenth century, Southeast Asia received an influx of European capital. Before this, foreign capital was invested first in agricultural, then in mining and shipping sectors: this was done directly by individual private entrepreneurs. However, over the course of time of this high colonial period, the colonial banking system became well-formed, and operated to facilitate the investment of European capital (Lindblad 1998). Through Western colonial banks, there was an influx of capital from home countries into the colonial economy. Western private banks as

\footnotetext{
${ }^{1}$ Population growth is estimated as follows: In Burma from 4,245,000 in 1870 to 19,488,000 in 1950; in Indonesia, from 28,922,000 in 1870 to 79,043,000 in 1950; in the Philippines, from 5,063,000 in 1870 to $21,131,000$ in 1950; in Thailand, from 5,775,000 in 1870 to 20,042,000 in 1950; and in Vietnam, from 10,146,000 in 1870 to 25,348,000 in 1950 (Maddison 2001: 213).
} 
well as colonial central banks were suppliers of capital for projects in Southeast Asia.

Banking became a key business for wealthy Chinese merchants and replaced tax farming developed in the nineteenth century. These merchants were engaged in the international transfer of money from Southeast Asia to mainland China. In addition, there were family bankers with their own capital, who lent money to small-scale overseas Chinese and indigenous Asian customers. Besides their own capital, some Chinese merchants were provided with capital by Western colonial banks, and they lent Western capital as brokers to local merchants and entrepreneurs.

\subsubsection{Increase of Chinese Immigrants}

The second key characteristic concerns Chinese immigrants. Not only Western impacts but also other Asian impacts were significant for the economic development of Southeast Asia. Among several Asians, the influence of overseas Chinese stands out (Skinner 1957; Claver 2014).

Continuing from the pre-early modern period, a vast number of Chinese people immigrated to Southeast Asia. While their geographical origins in mainland China were mostly in Fujian in the early modern period, the Chinese origins expanded to the provinces of Guangdong and Hainan after the mid-nineteenth century. When they arrived in Southeast Asia they began to work as manual laborers in several sectors such as plantation and mining or as dockworkers. Chinese immigrants were mostly male and although they eventually returned to China after several decades, some of them remained in Southeast Asia. Because Southeast Asia's population was scarce at the initial stage, Chinese immigrants were a very important source of labor.

Besides manual laborers, Chinese merchants were also key contributors to the Southeast Asian economy. They took on the role of entrepreneurs in several sectors. Mostly they were engaged in the commercial business. Since the early modern period overseas Chinese merchants managed retail shops in port cities and organized peddlers in the hinterland. Moreover, some of them were engaged in maritime trade by making use of their network comprising Southeast Asia and the Chinese coastal area. From the late nineteenth century onwards, exports to Asian countries increased in general, which would not have been realized without the Chinese network especially regarding exports to East Asia. When Western steam shipping companies emerged in Asian waters in the late nineteenth century, overseas Chinese merchants became key shippers. By and large, they functioned as maritime traders as well as mediators to connect international maritime trade with inland producers and consumers.

In addition to the commercial business, wealthy Chinese merchants extended their business interests to other sectors. Some of them invested in and managed a few industrial ventures such as plantation, food processing and mining. Before the beginning of large-scale European immigration in the twentieth century, overseas Chinese were almost the only ethnicity that ran the industrial sectors in Southeast Asia. On the other hand, tax farming was also a key business of wealthy overseas 
Chinese merchants. Several sorts of taxes such as market tax, gambling tax, and opium excises were collected mostly by these merchants, although tax farming was abolished from the late nineteenth century to the early twentieth century.

In this way, while Western and Chinese influences flourished at the height of colonialism, Southeast Asia made efforts to decrease the influence of Western and Chinese ethnic elements from the Great Depression of the 1930s and continued these efforts during the period of decolonization after the region's independence from colonial rule. The imaginary of the concept of nation-state building was useful for this purpose, although the characteristic of multi-ethnicity, historically accumulated in Southeast Asia remain in essence even today. In addition, in the context of international trade, the Southeast Asian economy was still a typical supplier of primary products to the West even after the region's independence, until the mid-1970s.

\subsection{The Contemporary Period and Conclusions}

This chapter traced the role of international trade in Southeast Asia's long-term path to socio-economic development, by dividing the region's history in accordance with changing relationships between trade and the economy and society. The relationships have been strong, and the economic development of Southeast Asia has been influenced by the changing trend of international trade. The region is located between China and India, both of which had been powerful economic forces, and has been economically and culturally influenced by the two civilizations. When Europeans participated in the trade of Southeast Asia in the early sixteenth century, the Southeast Asian economy was faced with greater demand for primary products. The high demand from outside Southeast Asia served as a strong motivation for socioeconomic changes in the region.

From the arrival of the Europeans to the mid-nineteenth century, Southeast Asia experienced the following changes: The development of international trade and the large demand for Southeast Asian products from outside the region resulted in the development of agricultural and mining sectors. With regard to agriculture, the plantation system was introduced, while small-scale peasant agriculture also developed. In both cases, these changes were reflections of the high demand for Southeast Asia's primary products in international trade. In addition, the mining sector and the plantation system needed immigrants and technology from outside. Both of them were managed by wealthy overseas Chinese merchants. On the other hand, European colonial cities gathered immigrants from Asia and Europe, which resulted in the general acceptance of multi-ethnic societies in port cities.

During the high colonial period, the development of international trade brought about economic changes in Southeast Asia. With the introduction of modern institutions, foreign merchants received benefits when conducting their business in Southeast Asia. These foreign merchants were not only European and American but also Chinese. In particular, overseas Chinese merchants were successful in banking and tax farming as well as in trade and commerce. These changes brought about by the 
development of international trade became distinctive characteristics of the Southeast Asian economy. They remain so today.

Large influences of international trade on the Southeast Asian economy continues to this day as well. Throughout the process of decolonization after World War II, the Southeast Asian economy acted as a supplier of primary products to Europe and USA. Rubber, rice, timber and sugar were the main items exported from Southeast Asia. However, in the mid-1970s, the economic links with East Asia became more significant. While the Japan's high-speed economic growth was put to an end in the early 1970s due to the Nixon Shock in 1971 and the oil crisis in 1973, South Korea, Taiwan, Hong Kong and even Singapore began to enjoy economic growth as Asian Newly Industrializing Economies (Asian NIEs). This gave a momentum to many Southeast Asian countries to treat economic links with Asian countries more seriously rather than sticking to traditional links with Europe and USA. Thus the Southeast Asian economy began to direct its path of economic development, with intra-Asian trade and the international division of labor in maritime Asia in mind. This meant that the region partly served as a supplier of resources (oil and natural gas, as well as agricultural, forestry and marine products) but also acted as a producer of manufactured goods, or at least of manufacturing parts as part of supply chains of manufactured goods, thus promoting industrialization. Of course, it is well-known that the process of the economic growth in the fourth quarter of the twentieth century was often accompanied by the developmental directorship, at least in the initial period.

To conclude, as seen in Fig. 3.1, the Southeast Asian economy has strong historical roots and has obtained considerable benefits from international trade. Since the entry of the Europeans in the beginning of the sixteenth century in particular, Southeast Asia has been in touch with a wide range of overseas markets in Asia and Europe. Large demands for Southeast Asian products have stimulated the economic development of the region. The economy was largely developed for the mass production of primary products. Development of the delta areas, introduction of the plantation system, and the acceptance of Chinese immigrants are good examples of the region's capacity to respond to changes, before the production of manufactured goods became more important in the late twentieth century.

\section{References}

Abushouk, A. I., \& Ibrahim, H. A. (Eds.). (2009). The Hadhrami diaspora in Southeast Asia: Identity maintenance or assimilation?. Leiden and Boston: Brill Academic Publishers.

Andaya, B. W., \& Andaya, L. Y. (2015). A history of early modern Southeast Asia, 1400-1830. Cambridge: Cambridge University Press.

Barnard, T. P. (2003). Multiple centres of authority: Society and environment in Siak and eastern Sumatra, 1674-1827. Leiden: KITLV Press.

Blussé, L. (1986). Strange company: Chinese settlers, mestizo women, and the Dutch in VOC Batavia. Dordrecht: Foris Publications. 
Blussé, L. (1999). Chinese century: The eighteenth century in the China Sea region. Archipel, 58(3), $107-129$.

Claver, A. (2014). Dutch commerce and Chinese merchants in Java: Colonial relationships in trade and finance, 1800-1942. Leiden and Boston: Brill Academic Publishers.

Crosby, A. W., Jr. (1972). The Columbian exchange: Biological and cultural consequences of 1492. Westport: Greenwood Press.

Elson, R. E. (1994). Village Java under the cultivation system, 1830-1870. St Leonards: Allen and Unwin.

Hall, K. R. (2011). A history of early Southeast Asia: Maritime trade and societal development, 100-1500. Lanham: Rowman \& Littlefield.

Hardy, A., Cucarzi, M., \& Zolese, P. (Eds.). (2009). Champa and the archaeology of Mỹ Son (Vietnam). Singapore: NUS Press.

Jacobs, E. M. (2006). Merchants in Asia: The trade of the Dutch East India Company during the eighteenth century. Leiden: CNWS Publications.

Kagotani, N. (1995). The role of Chinese merchants in the development of the Japanese cotton industry, 1880-1934. Zinbun: Annals of the institute for research in humanities, Kyoto University, $30,149-183$.

Kathirithamby-Wells, J., \& Villiers, J. (Eds.). (1990). The Southeast Asian port and polity: Rise and demise. Singapore: Singapore University Press.

Lieberman, V. (2003). Strange parallels: Southeast Asia in global context, c. 800-1830, Vol. 1: Integration on the mainland. Cambridge: Cambridge University Press.

Lindblad, J. T. (1998). Foreign investment in Southeast Asia in the twentieth century. Basingstoke: Macmillan Press.

Liu, Y., Chen, Z., \& Blue, G. (Eds.). (2014). Zheng He's maritime Voyages (1405-1433) and China's relations with the Indian Ocean world: A multilingual bibliography. Leiden and Boston: Brill Academic Publishers.

Maddison, A. (2001). The world economy: A millennial perspective. Paris: OECD.

Munoz, P. M. (2006). Early kingdoms of the Indonesian Archipelago and the Malay Peninsula. Singapore: Editions Didier Millet.

Raben, R. (1996). Batavia and Colombo: The ethnic and spatial order of two colonial cities, 1600-1800. Unpublished PhD thesis, Leiden University.

Reid, A. (1997). Introduction. In A. Reid (Ed.), The last stand of Asian autonomies: Responses to modernity in the diverse states of Southeast Asia and Korea, 1750-1900 (pp. 1-25). London: Macmillan Press.

Shimada, R. (2006). The intra-Asian Trade in Japanese copper by the Dutch East India Company during the eighteenth century. Leiden and Boston: Brill Academic Publishers.

Shimada, R. (2013). The long-term pattern of maritime trade in Java from the late eighteenth century to the mid-nineteenth century. Southeast Asian Studies, 2(3), 475-497.

Shimada, R. (2015). Hinterlands and port cities in Southeast Asia's economic development in the eighteenth century: The case of tin production and its export trade. In T. Mizushima, G. B. Souza, \& D. O. Flynn (Eds.), Hinterlands and commodities: Place, space, time and the political economic development of Asia over the long eighteenth century (pp. 197-214). Leiden and Boston: Brill Academic Publishers.

Shimada, R. (2018). Invisible links: Maritime trade between Japan and South Asia in the early modern period. In A. J. H. Latham \& H. Kawakatsu (Eds.), Asia and the history of the international economy: Essays in memory of Peter Mathias (pp. 57-71). London and New York: Routledge.

Skinner, G. W. (1957). Chinese society in Thailand: An analytical history. Ithaca: Cornell University Press.

Somers Heidhues, M. (2003). Golddiggers, farmers, and traders in the "Chinese districts" of West Kalimantan, Indonesia. Ithaca: Southeast Asia Program Publications, Cornell University.

Souza, G. B. (1986). The survival of empire: Portuguese trade and society in China and the South China Sea, 1630-1754. Cambridge: Cambridge University Press. 
Sugihara K. (1996). Ajia kan boeki no keisei to kozo (The Formation and structure of intra-Asian trade). Kyoto: Minerva Shobo: 1996.

Sugihara, K. (2001.) Kokusai bungyo to tonan ajia shokuminchi keizai (The international division of labor and the Southeast Asian colonial economy). In H. Kano (Ed.), Shokuminchi keizai no hanei to choraku (Prosperity and decline of the colonial economy), Tonan ajiashi (Southeast Asian history) (Vol. 6, pp. 249-272). Tokyo: Iwanami Shoten.

Yao, K. (2003). Two rivals on an island of sugar: The sugar trade of the VOC and overseasChinese in Formosa in the seventeenth century. In L. Blussé (Ed.), Around and about Formosa: Essays in honor of Professor Ts'ao Yung-ho (pp. 129-140). Taipei: Ts'ao Yung-ho Foundation for Culture and Education.

Open Access This chapter is licensed under the terms of the Creative Commons AttributionNonCommercial-NoDerivatives 4.0 International License (http://creativecommons.org/licenses/bync-nd/4.0/), which permits any noncommercial use, sharing, distribution and reproduction in any medium or format, as long as you give appropriate credit to the original author(s) and the source, provide a link to the Creative Commons licence and indicate if you modified the licensed material. You do not have permission under this licence to share adapted material derived from this chapter or parts of it.

The images or other third party material in this chapter are included in the chapter's Creative Commons licence, unless indicated otherwise in a credit line to the material. If material is not included in the chapter's Creative Commons licence and your intended use is not permitted by statutory regulation or exceeds the permitted use, you will need to obtain permission directly from the copyright holder.

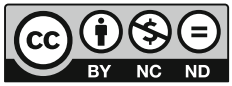

